\title{
The Effect of Using Flipped Classroom on Developing Essay \\ Writing Skills and Attitude towards Writing in English for University Students
}

\author{
Dr. Fawzia Hassan Barakat
}

Lecturer of Curriculum and Instruction

Cairo Higher Institutes

Cairo Higher Institute for Languages and Interpretation

\section{Abstract}

This research aimed at investigating the effect of using flipped classroom on developing most necessary essay writing skills and attitude towards writing in English for $1^{\text {st }}$ year Cairo Higher Institute for Languages and Interpretation students. Participants of the research were randomly selected and divided into two groups (40) for the experimental group and (40) for the control group. The research prepared and employed an essay writing skills' test and a writing attitude scale. The necessary essay writing skills for $1^{\text {st }}$ year Cairo Higher Institute for Languages and Interpretation students were determined through the use of a checklist approved by a jury of specialists in teaching EFL. During the experiment, the experimental group received instruction through using flipped classroom, while the control group received regular instruction. The experiment lasted for two months. The quasi experimental design was followed. The statistical analysis of the obtained data from the administrations of the test confirmed the effect of flipped classroom on developing essay writing skills and attitude towards writing in English for $1^{\text {st }}$ year Cairo Higher Institute for Languages and Interpretation students. Thus, the aim of the research was achieved as using flipped classroom showed a large effect size on developing the essay writing skills and attitude towards writing in English for the participants of the experimental group. Based on the results, it was recommended that instructors should give due attention to the development of essay writing skills and attitude towards writing in English for university students through 


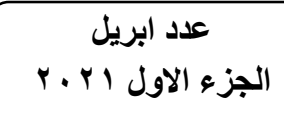

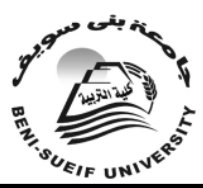

جامعة بني سويف مجلة كلية التربية

flipped classroom. In addition, using flipped classroom in developing other language skills was suggested.

\section{Key words:}

Flipped Classroom - Essay Writing Skills - Attitude towards Writing 


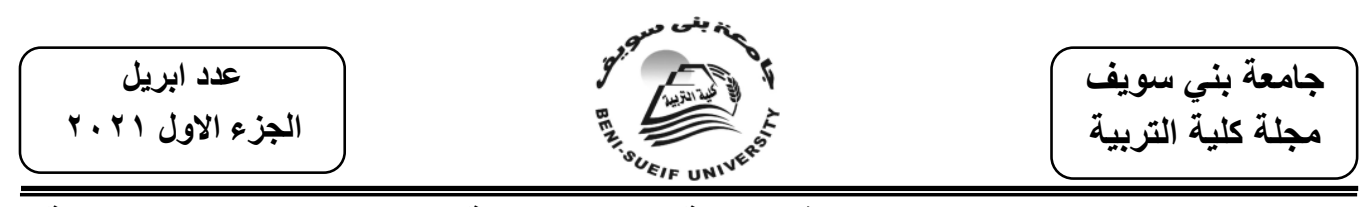

أثر استخدام الفصل الدراسي المقلوب في تنمية مهارات كتابة المقال والإتجاه نحو الكتابة

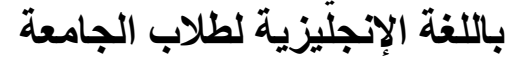

إعداد

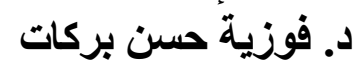

مدرس المناهج وطرق التدريس اللغة الإنجليزية

معاهد القاهرة العليا

معهد القاهرة العالي للغات و الترجمة الفورية

المستخلص

هدفت الدراسة إلى التحقق من أثز استخدام الفصل الدراسي المقلوب في تتمية مهارات كتابة المقال والإتجاه نحو الكتابة باللغة الإنجليزية لدي طلاب الفرقة الأولى بمعهد القاهرة العالي للغات والترجمة الفورية بالمقطم. وقد تكونت عينة البحث من (•^) طالبًا وتم تقسيمهم الإه

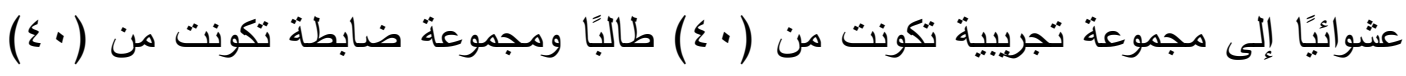
طالبًا وتم تصميم قائمة بمهارات كتابة المقال تحتوي على مهارات كتابة المقال اللازمة لطلاب الفرقة الأولى. كما تم اعداد اختبارًا لمهارات كتابة المقال وكذلك مقياس الإتجاه نحو الكتابة باللغة الإنجليزية. وقد استخدم البحث المنهج الوصفي التحليلي والثبه التجريبي وقد نم استخدام الفصل الدراسي المقلوب في تتمية مهارات كتابة المقال مع المجموعة التجريبية وطريقة التدريس المعتادة مع المجموعة الضابطة و قد تم عمل التحليل الإحصائى وأسفرت النتائج عن أثر استخدام الفصل الدراسي المقلوب في تتمية مهارات كتابة المقال والإتجاه نحو الإس الكتابة باللغة الإنجليزية لدي طلاب الفرقة الأولى بمعهد القاهرة العالي للغات والترجمة الفورية بالمقطم. وبالتالى تجقق الهدف من البحث؛ حيث أن حجم الأثر لاستخدام الفصل الدراسي المقلوب كان كبير في تتمية مهارات كتابة المقال والإتجاه نحو الكتابة باللغة الإنجليزية لطلاب الفرقة الأولى. و قد أوصى البحث بضرورة اهتمام المعلمين بتتمية مهارات كتابة المقال والإتجاه نحو الكتابة باللغة الإنجليزية لطلاب الفرقة الأولى بمعهد القاهرة العالي للغات والترجمة الفورية بالمقطم باستخدام الفصل الدراسي المقلوب. وقد اقترح البحث استخدام الفصل الدراسي المقلوب فى تتمية مهارات لغوبة أخري.

الكلمات المفتاحية : الفصل الدراسي المقلوب - مهارات كتابة المقال - الإتجاه نحو الكتابة 


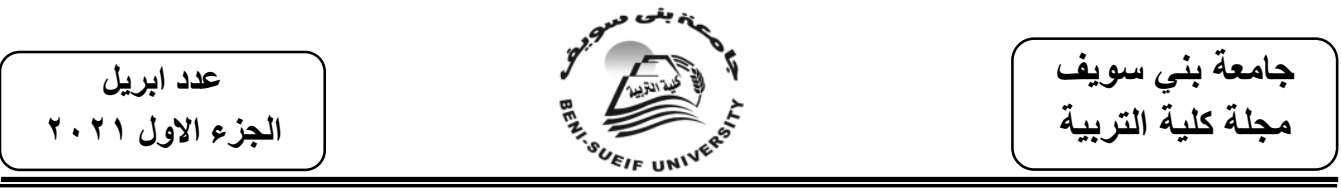

\section{Introduction}

In the $21^{\text {st }}$ century, technology increases speedy access to information, and the Internet can be easily accessed through various technology tools such as smartphones, computers, and laptops. Technology has become an essential part of educational process. Using technology in language classroom is a phenomenon in which face-toface teaching and learning experiences are associated with online activities and tasks.

Consequently, this increase of technology progress has influenced the development of instructional technology in education and changed the use of the blackboard to online video lectures (Evans, 2011, p. 4). In recent times, the flipped classroom has become one of developing technologies in education and instruction as it can be a standard of teaching-learning practice to raise students' active learning in higher education (Hamdan, McKnight, McKnight, \& Arfstrom, 2013, p.5).

Writing as one of English language skills is a vital and essential skill in today's world. It is also a predictor of success in college and career. In order to acquire the necessary writing skills, students must not only be taught how to write, but should also be provided with sufficient opportunities to practice their developing skills (Soiferman, 2017, p. 66).

Also, Choi (2010, p.13) assured that an increasing need of proficient English writing skills has been consequently requesting effective English writing education. For better writing instruction, there has been a continual development of theories and instructional practices in English writing education.

While essay writing is important to acquire English language, students may face some problems or difficulties while writing in English as a foreign language. The first problem is that students lack the proper use of grammar (tenses, sentence structures). The second 
problem is that students have challenges in the use of correct spelling. Another very common problem is that students have difficulties in using cohesion and coherence in essay writing and negative attitude towards learning essay writing skills. (Alfaki, 2015, p.45).

In addition, a number of studies such as the studies of Ahmed (2010), Fahim and Hashtroodi (2012), Alodwan and Ibnian (2014), and Afifi, seleim and Michel (2016) emphasized the fact that EFL essay writing skills are neglected in university level despite their great importance in learning English and their relevance to other language skills. So, there was a bad need for using new strategies to develop EFL essay writing skills.

Additionally, as stated by Petric (2002, p.9) it is generally acknowledged that positive writing attitudes lead to positive writing experiences which in sequence lead to higher academic performance. Besides, Tunks (2010) indicated that students' positive attitude towards an academic topic has an effect on their motivation to learn, which in turn influence them during writing tasks.

Moreover, Clark (2012, pp. 5-6) showed that instructors must investigate to understand and learn about their students' attitudes towards writing. This should be done because attitude is an important factor that plays a great part in students' literacy learning. Attitude affects motivation to learn and write and influences how students proceed towards the task of writing.

Furthermore, a number of studies pointed out that different strategies should be used to develop students' attitudes toward writing such as Ibrahim's study (2006) showed that using the reading for writing approach is important for developing students' attitudes toward writing. Also, Lan, Hung, and Hsu's study (2011) declared that using guided writing strategies is necessary for developing students' attitudes toward writing. Moreover, Elashri's study (2013) assured that using the genre based approach is essential for developing students' attitudes 


$$
\begin{aligned}
& \text { عدد ابريل }
\end{aligned}
$$

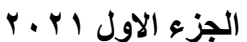

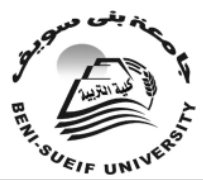

\section{جامعة بني سويف كايف \\ مجلة كلية التربية}

toward writing. Okasha and Hamdi's study (2014) used strategic writing techniques to develop students' attitudes toward writing.

So, students' writing attitudes have a large impact on their academic achievement and performance. From what is mentioned above as well as previous studies, there is a necessity for building more positive writing attitudes in our society.

Therefore, the researcher after reviewing the literature and previous studies saw that using flipped classroom is important for developing the most necessary essay writing skills and attitude towards writing in English for $1^{\text {st }}$ year Cairo Higher Institute for Languages and Interpretation students for the following reasons:

1. The use of flipped classroom gives students opportunity to be taught how to stay attentive, to collaborate with peers, and to be well-organized. (Finkel, 2012, p.29)

2. Students have the opportunity to learn from taped videos of instruction that allowed them unlimited opportunities to watch the videos as often as needed. (Hamdan et. al., 2013, p.64)

3. According to Egbert, Herman and Lee (2015, p.18) flipped classroom helps students to practise many activities and tasks and writing skills require applying many activities under instructor's guide and assistance.

4. In flipped classrooms, students tend to be more active compared with traditional classrooms: they will learn independently with the guidance of technology devices and the lecturer will act as a facilitator. (Zainuddin \& Attaran, 2016, p.661)

Based upon what is mentioned above, it is clear that using flipped classroom is so important in developing writing skills. So, the present research tried to investigate the effect of using flipped classrooms on developing most necessary essay writing skills and attitude towards writing in English for $1^{\text {st }}$ year Cairo Higher Institute for Languages and Interpretation students in an attempt to solve a due problem they face in learning English. 


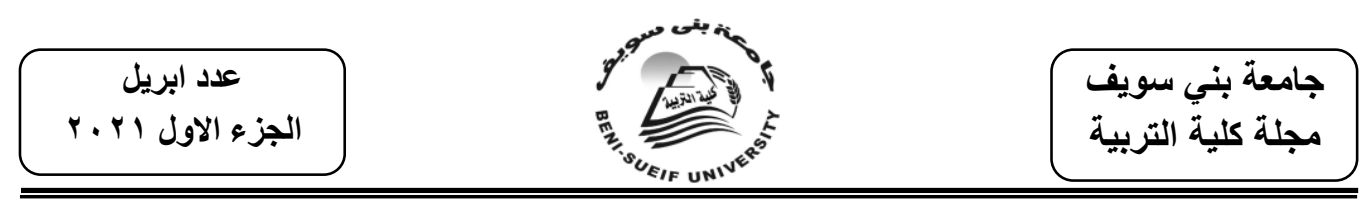

\section{Context of the Problem}

The problem of the current research was derived from the following resources:

First: To the extent that the researcher knows, owing to her work as teaching staff of TEFL, $1^{\text {st }}$ year students enrolled at Cairo Higher Institute for Languages and Interpretation encounter difficulties in essay writing skills. They cannot write a good essay that contains indicators of an essay (grammar, word choice, mechanics and organization skills), and their performance revealed weakness in their writing skills. Also, they have negative attitude towards writing in English.

Second: The problem of the research was further supported by reviewing previous related studies. Recent related studies such as Ahmed (2010), Fahim, and Hashtroodi (2012), Alodwan and Ibnian (2014), and Afifi, et. al. (2016) assured the weakness of EFL students in essay writing skills and recommended finding new strategies, methods and techniques to develop these skills. Also, reviewing previous related studies such as the studies of Ibrahim (2006), Lan, et. al. (2011), and Elashri (2013). These studies emphasized the fact that EFL students' attitudes toward writing are neglected despite their great importance in learning. So, there was a bad need for using new strategies to develop EFL students' attitudes toward writing.

Third: The researcher designed and administered an essay writing skills test to the $1^{\text {st }}$ year students to approve, document and analyze the information derived from the review of the related previous studies. Students' answers revealed the profound weakness in their essay writing skills and are in a dire need of developing their essay writing skills.

Fourth: The researcher designed and administered a writing attitude scale in order to measure students' attitudes toward writing and confirm the information derived from the review of the related previous studies. The scale was composed of (20) statements. Results of this scale showed that students had negative attitudes toward writing. 


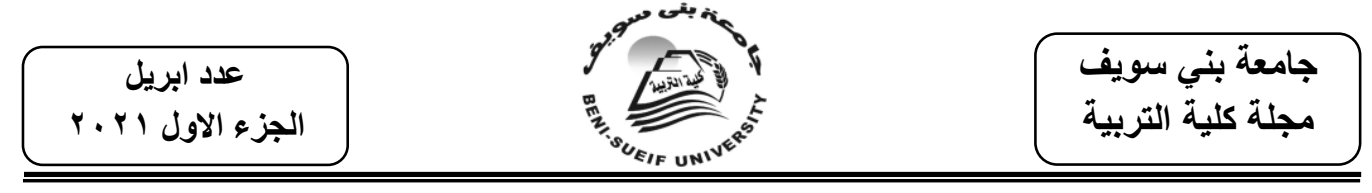

Accordingly, it was doubtless that those students were in dire need of developing their essay writing skills and developing their attitudes toward writing in English.

\section{Statement of the Problem}

The research problem could be summarized in the following statement:

$1^{\text {st }}$ year students, Cairo Higher Institutes for Language and Interpretation, lacked some of the essay writing skills most necessary for them and have negative attitude towards writing.

\section{Questions of the Research}

To tackle this problem, the present research attempted to answer the following main question:

"What is the effect of using flipped classroom on developing the most necessary essay writing skills and attitude towards writing for the $1^{\text {st }}$ year students of Cairo Higher Institute for Languages and Interpretation?"

From this question, the following sub questions emerged:

1. What are the most necessary EFL essay writing skills for the $1^{\text {st }}$ year students of Cairo Higher Institute for Languages and Interpretation?

2. What are the features of the proposed framework using flipped classroom to develop the most necessary essay writing skills and attitude towards writing for the $1^{\text {st }}$ year students of Cairo Higher Institute for Languages and Interpretation?

3. What is the effect of using flipped classroom on developing the most necessary EFL essay writing skills of the $1^{\text {st }}$ year students of Cairo Higher Institute for Languages and Interpretation? 
4. To what extent will the effect of flipped classroom on EFL essay writing skill vary from one trait to another?

5. What is the effect of using flipped classroom on developing attitude towards writing of the $1^{\text {st }}$ year students of Cairo Higher Institute for Languages and Interpretation?

\section{Hypotheses of the Research}

The present research hypothesized that:

1. There is a statistically significant difference between the experimental group and the control group students' mean scores on the post-administration of the essay writing skills test in favour of the experimental group.

2. There is a statistically significant difference between the experimental group's mean scores on the pre and postadministrations of the essay writing skills test in favour of the post-administration.

3. There is a statistically significant difference between the experimental group students' mean scores in each essay writing trait on the pre and post-administrations of the essay writing skills test in favour of the post-administration.

4. The proposed framework using flipped classroom has a large effect size on developing each essay writing trait.

5. There is a statistically significant difference between the experimental group and the control group students' mean scores on the post-administration of the writing attitude scale in favour of the experimental group

6. There is a statistically significant difference between the experimental group's mean scores on the pre and postadministrations of the writing attitude scale in favour of the postadministration. 


$$
\begin{aligned}
& \text { عدد ابريل }
\end{aligned}
$$

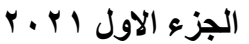

\section{Variables of the Research}

Independent Variable: This referred to the treatment implemented with the experimental group in this research (the proposed framework using flipped classroom).

Dependent Variable: This referred to the development in the experimental group's essay writing skills targeted and attitude towards writing by the treatment.

\section{Aims of the Research}

This research aimed at:

1. Identifying the EFL essay writing skills most necessary for the $1^{\text {st }}$ year students of Cairo Higher Institute for Languages and Interpretation.

2. Developing the EFL essay writing skills of $1^{\text {st }}$ year students of Cairo Higher Institute for Languages and Interpretation through designing a proposed framework using flipped classroom.

3. Developing the EFL attitude towards writing of the $1^{\text {st }}$ year students of Cairo Higher Institute for Languages and Interpretation through designing a proposed framework using flipped classroom.

4. Measuring the effect of the proposed framework using flipped classroom on developing the EFL essay writing skills of the $1^{\text {st }}$ year students of Cairo Higher Institute for Languages and Interpretation.

5. Measuring the effect of the proposed framework using flipped classroom on developing the EFL attitude towards writing of the $1^{\text {st }}$ year students of Cairo Higher Institute for Languages and Interpretation.

\section{Significance of the Research}

The present research's significance lies in the fact that it was an attempt to improve essay writing skills and attitude towards writing for the $1^{\text {st }}$ year students of Cairo Higher Institute for Languages and Interpretation and it is hoped that the research results would contribute to:

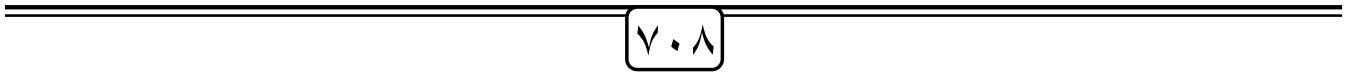


1. Further affirmation on the importance of developing most necessary essay writing skills and attitude towards writing for the $1^{\text {st }}$ year students of Cairo Higher Institute for Languages and Interpretation.

2. Attracting the attention to the importance of using flipped classroom in developing essay writing skills and attitude towards writing.

\section{Delimitations of the Research}

The present research was delimited to the following:

1. A sample of eighty $1^{\text {st }}$ year students of Cairo Higher Institute for Languages and Interpretation.

2. Developing only the most necessary essay writing skills and attitude towards writing for the $1^{\text {st }}$ year students of Cairo Higher Institute for Languages and Interpretation. Four essay writing traits; namely: grammar, mechanics, word choice, and essay organization \& sentence fluency (nineteen EFL essay writing skills) were identified and judged to be the most important for $1^{\text {st }}$ year students of Cairo Higher Institute for Languages and Interpretation.

3. Using flipped classroom in teaching (15) essay writing lessons to $1^{\text {st }}$ year students of Cairo Higher Institute for Languages and Interpretation.

4. A limited duration for implementing flipped classroom to $1^{\text {st }}$ year students of Cairo Higher Institute for Languages and Interpretation. (two lectures per week over a period of two months).

\section{Definitions of Terms}

\section{Flipped Classroom:}

According to Bishop and Verleger (2013, p.5) the flipped classroom is defined as an instructive technique that involves two parts; interactive group learning activities inside the classroom, and direct computer-based individual instruction outside the classroom. 
عد ابريل

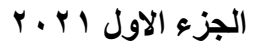

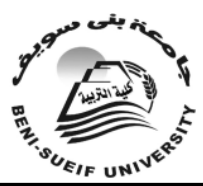

جامعة بني سويف

Also, AlJaser (2017, p.69) defined the flipped classroom as an educational learning model focuses on learners and aims at replacing the traditional lecture by active cooperative tasks using internet and computer technology to convey a video lecture to be watched at home; and then learners discuss it through some tasks and activities.

In the present research, flipped classroom is defined as a learnercentered learning strategy which facilitate $1^{\text {st }}$ year Cairo Higher Institute for Languages and Interpretation students' learning outside class via watching recorded videos at home through Google Classroom Platform and learning within class through tasks and activities with the guidance of the instructor.

\section{Essay Writing:}

Fawcett (2010, p.173) defined an essay as a group of paragraphs about a single subject. It usually consists of the introduction containing a thesis statement, the body and the conclusion.

According to Villalon and Calvo (2011, p.17) an essay is a piece of writing made up of a number of paragraphs.

In the present research, an essay is defined as a piece of writing written by $1^{\text {st }}$ year Cairo Higher Institute for Languages and Interpretation students discussing a topic and handling relevant ideas which are clearly expressed, and has a defined structure - an introduction, a body, and a conclusion.

\section{Attitude towards Writing:}

Writing attitude is defined by Graham, Berninger, and Abbott (2007, p.55) as an emotional mood involving how the performance of writing makes the author feel, ranging from happy to unhappy. In other 


$$
\begin{aligned}
& \text { عدد ابريل }
\end{aligned}
$$

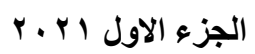

words, the more positive attitude students have towards writing, the more energy they spend on the task.

Also, Erdogan (2013, p.45) defined attitude towards writing as an affective feature that associated with how individual feels himself/herself while writing.

In the present research, attitude towards writing is defined operationally as how the students feel about what they write and it is measured by the writing attitude scale which prepared by the researcher for this purpose.

\section{Theoretical Background}

This part is divided into three sections. The first section is concerned with using flipped classroom. The second one focuses on essay writing skills while the third one discusses attitude towards writing skills. The following part will deal with them in more details.

\section{First Section: Flipped Classroom:}

According to Roehl, Reddy, and Shannon (2013, p.44) flipped classroom employs easy-to-use, easily accessible technology to free class time from lecture. This permits for an extended choice of learning activities during class time. Using class time for active learning versus lecture offers chances for greater teacher-to-student guidance, peer-topeer cooperation and students' engagement in the learning process.

\section{The Instructor's Role in the Flipped Classroom:}

In the flipped classroom the instructor's role changes to guide students and moves them away from being inactive receivers of static knowledge to engaging participants that realize and comprehend learning objectives on their own (Brown, 2012, p.87). 
عدد ابريل

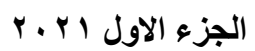

Also, Kachka (2012, p.1) recommends that during the in-class activities, the instructor must be cautious to observe and rise the interaction with the learners. In addition, the instructional design using technology needs to be carefully planned to confirm the students' learning experience is enhanced, where students identify learning as their goal.

According to Houston and Lin (2012, p.1181) the process of just flipping a classroom will not change students' learning, a successful employment of a flipped classroom would need the videos to be relatively short (no longer than 20 minutes) and instructors should briefly review the course content before in-class activities to answer any questions and to make sure that the majority of the students have adequate understanding of the material.

From what is mentioned above it is clear that instructors play a great role in the flipped classroom as they guide learners during classroom activities, monitor and increase the interaction with the learners and answer any questions to help them understand the material.

\section{The Students' Role in the Flipped Classroom:}

In flipped classroom, students review pre-recorded lecture content online before class, freeing class time for active learning. Student changes from inactive receiver of knowledge to active promoter of knowledge. In this approach the roles of students are expressed below:

- Taking their own learning responsibilities. (Bergmann \& Sams, 2012, p.16)

- Watching lecture videos before the course and preparing for the course by using learning materials. (Milman, 2012, p.85)

- Making essential interactions with his teacher and classmates, taking and giving feedback. (Tucker, 2012, p.82)

- Participating discussions within class. (Overmyer, 2012, p.46) 
From what is mentioned above it is clear that learners' role changed in the flipped classroom from inactive learners to be very active as they can depend on themselves during watching instructional online videos, they can prepare questions for their instructors and classmates, and participate in discussions in the classroom.

\section{Pillars of Flipped Classroom}

Because flipped classroom emphasises on meeting individual student learning needs, a team of experienced instructors from the Flipped Learning Network (2014, para. 2) identified the key features, or pillars, of flipped classrooms. The four Pillars are as follows:

1. Flexible environments: Instructors often physically reorganize their learning space to accommodate the lesson, which might involve group work, independent study, research, performance, and evaluation. They create Flexible Environments in which students choose when and where they learn.

2. Learning Culture: The classroom becomes learner-centred. Students move from being the product of teaching to the centre of learning, where they are actively involved in knowledge formation through opportunities to participate in and evaluate their learning in a way that is personally meaningful. Learners can theoretically pace their learning by reviewing content outside the group learning space, and instructors can maximize the use of face-to-face classroom interactions to check for and ensure learner understanding and synthesis of the material.

3. Intentional Content: Instructors are required to evaluate what they need to teach directly so that classroom time can be used for other methods of teaching, such as "active learning strategies, peer instruction, problem-based learning, or mastery or Socratic methods, depending on grade level and subject matter."

4. Professional Educators: The instructional videos used for flipped classrooms cannot replace professional instructors. They must determine when and how to shift direct instruction from the 
عدد ابريل

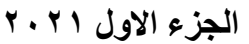

group to the individual learning space, and how to maximize the face-to-face time between instructors and learners. During class time, instructors frequently observe their learners, provide them with significant feedback, and continuously assess their work.

\section{Benefits and Advantages of Using Flipped Classroom:}

Fulton (2012, pp.20-24) assumed the following among the advantages of the flipped classroom:

1) Students move at their own pace;

2) Doing assignments in class gives instructors better idea about learners' difficulties and learning styles;

3) Instructors can modify and update the curriculum and provide it to learners;

4) Classroom time can be used more efficiently and creatively;

5) Using this method helps teachers increase levels of learner interest, engagement, and achievement;

6) The use of technology is flexible and appropriate for $21^{\text {st }}$ century learning.

Consequently, by applying the flipped classroom approach to teaching and learning activities, the instructor can transfer the traditional lecturer's talk to video and the learners can listen to the lectures anywhere outside of class. The flipped classroom allows learners to watch the video according to their preferred time and need, and they can study at their own pace; this type of activity also increases students' cooperative learning in distance education outside the class. (Zainuddin, \& Halili, 2016, p.315)

Also, Danker (2015, p.183) assured that using flipped classroom restructures lectures into an active-learning which lead learners to be involved in learning, where they can participate, receive feedback and develop their thinking skills. The class is no longer a place where learners are passively placed and only take notes, but now is active with learners who are interacting and realizing the lesson together. The 


$$
\begin{aligned}
& \text { عدد ابريل }
\end{aligned}
$$

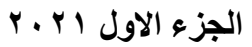

flipped classroom strategy promoted individualised learning for learners as some of the learners used the opportunity to replay and pause the online lecture to absorb it better.

Moreover, Harris, Harris, Reed, and Zelihic (2016, p.325) indicated that the flipped classroom offers learners with a diversity of means to study basic knowledge content as part of homework and preparation for class meetings; instructors then use class time more effectively for hands-on activities or other means of encouraging students to practise, apply and reveal mastery of the content learned from the pre-class requirements.

Furthermore, Offerman-Celentano $(2017$, p.8) indicated that by providing lecture content at home via video lessons, teachers attempt to use valuable face-to-face time in the classroom with individual learners. The ultimate goal is to provide more individualised to address learner academic, social, and emotional needs.

From what is mentioned above it is clear that flipped classroom is a learner-centred approach where the learners are more active in the classroom activity. In this case, the lecturer performs as a director to motivate, guide, and give feedback on learners' performance. Moreover, using flipped classroom encourages collaboration among learners and increases learners' responsibility for their own learning.

\section{Principles of the Flipped Classroom Instruction (FCI)}

The Flipped Classroom Instruction implies a reversal of the normal class set up and the shift between class instruction and homework. What happens through a FCI approach is that learners obtain the basic information outside of class, raising their learning, enjoying the autonomy of studying online for further learning. They pause videos to reflect on what is being said, reverse to hear it again, listen to as much or as little of the lecture as their schedules permit, and 
عدد (بريل

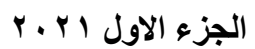

view the lecture on a mobile device rather than in a fixed location. (Talbert, 2012, p. 1)

Also, Kim, Kim, Khera, and Getman (2014, p.28) stated that the principles for the flipped classroom are as follows:

- Providing an opportunity for learners to gain introductory information before the class activity,

- Encouraging learners to watch online lectures and be prepared before the class activity,

- Organizing ways of assessment,

- Linking in-class activities with out-of-class activities,

- Supplying clearly specified and well organized guidance,

- Providing sufficient time for completing assignments,

- Promoting learners to build a learning community,

- Offering immediate feedback on individual or group works,

- Providing the use of familiar technologies which can be accessed easily by students.

\section{Assessment in Flipped Classroom:}

According to Bergmann and Sams (2012, pp. 81-84) assessment system in flipped classroom can be divided into formative and summative as follows:

\section{Formative Assessment:}

In formative assessment, instructors talk to their learners, get to know them, learn how they think, and help them learn how to learn. Because instructors knew their learners well, and because they knew to what extent they understand each learning objective, they vary their questions based on learners' understanding. Flipped classroom gives the instructor opportunities to ask a lot of questions. Instead of asking the question one time during a lecture, the instructor can ask learners and interact with each of them and modify specific questions to meet learners' individual learning needs. 


\section{Summative Assessment:}

In summative assessment, learners must show a minimum level of proficiency. Many models of assessment exist for the instructor. Exams can be scored out of total points, objectives can be assessed individually on a $0-4$ scale, or a test can represent a straight percentage. There is no single way to flip, no single way to assess, and no single way to give learners feedback. Instructors must do what is best for learners and operate within the parameters of particular educational setting.

There are some studies used flipped classroom in English as a foreign language and these studies examined and explained the advantages of using flipped classroom in language learning such as:

- Davies, Dean, and Ball (2013) explored the benefits of flipping the classroom on college students. They found that the flipped classroom was effective and facilitated learning. Most of the students in the flipped classroom indicated their willingness to take another course as they found the experience to be more motivating.

- Al-Zahrani (2015) carried out a study to examine the influence of the flipped classroom on promoting of learners' creative thinking at King Abd-ulaziz University in Saudi Arabia. The researcher concluded that the flipped classroom may promote students' creativity, especially with regard to fluency, flexibility and novelty.

- Evseeva and Solozhenko (2015) examined the usefulness of the flipped classroom in the process of English language teaching and learning of second year students studying at The National Research Tomsk Polytechnic University. They reported several benefits for the flipped classroom such as offering instructors the 
ع عداد ابريل

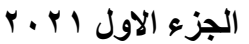

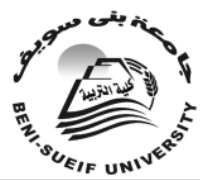

\section{جامعة بني سويف \\ مجلة كلية الثربية}

flexible timetable, and engaging the learners in the learning process and increasing their academic performance.

- Unakorn and Klongkratoke (2015) conducted a study to examine the effectiveness of using flipped classroom. They stated that flipped classroom enabled learners to have more efficient management for time in classroom and a better achievement in learning. Additionally, it provided learners with more opportunities to communicate with each other and their instructor.

- Hashemifardnia, Namaziandost, and Shafiee (2018) investigated the effect of implementing flipped classrooms on Iranian junior high school students' reading comprehension. The findings revealed that the experimental group significantly outperformed the control group $(\mathrm{p}<.05)$ on the post-test.

\section{Second Section: Essay Writing Skills}

\section{Importance of Writing:}

Ariana (2010, p.134) stated that writing skills help the learner to become fluent, intelligible, independent, and creative in writing, important abilities which help learners put their thoughts in a meaningful form and to mentally tackle the message in an appropriate way.

Also, Maghsoudi, and Haririan (2013, p.60) asserted that writing has always considered a significant skill in the teaching and learning English as a foreign Language (EFL). On the one hand, it provokes learners' thinking, requires learners to concentrate and organize their ideas, and promotes their ability to summarize, analyse, and criticise. On the other hand, it strengthens learning, thinking, and reflecting on the English language. 
According to Saed \& Al-Omari (2014, p.88) writing has been commonly regarded as a critically vital skill in the teaching and learning of English as a Second Language (ESL) as it is a comprehensive skill that helps reinforce vocabulary, grammar, thinking, planning, editing, revising, and other elements. Writing also helps to develop all the other skills of reading, listening, and speaking as they are all interrelated.

It is clear that writing is considered as a vital skill in the teaching and learning of English as it strengthens students' thinking, vocabulary, and grammar. It also supports students' ability to summarize and develops different language skills such as listening, speaking and reading.

\section{Types of Essays Writing:}

Kiester (2013, p.69) stated that there are four types of essays. They are as follows:

1. Narrative Essays: In a narrative essay, the writer tells a story about a real-life experience. While telling a story may sound easy to do, the narrative essay challenges learners to think and write about themselves. When writing a narrative essay, writers should try to involve the reader by making the story as vivid as possible. The fact that narrative essays are usually written in the first person helps engage the reader.

2. Descriptive Essays: Descriptive essays paint a picture with words. A writer might describe a person, place, object, or even memory of special importance. The descriptive essay attempts to communicate a deeper meaning through the description. In a descriptive essay, the writer should show, not tell, through the use of colourful words and sensory details.

3. Expository Essays: An expository essay is an informative piece of writing that presents a balanced analysis of a topic. In an expository essay, the writer explains or defines a topic, using facts, statistics, and examples. It includes a wide range of essay 
عدد ابريل

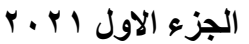

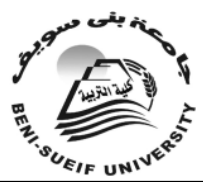

\section{جامعة بني سويف \\ مجلة كلية التربية}

variations, such as the comparison and contrast essay, the cause and effect essay, and the "how to" or process essay.

4. Persuasive Essays: The goal of the persuasive essay is to persuade the reader to accept the writer's point of view or recommendation. The writer must build a case using facts and logic, as well as examples, expert opinion, and sound reasoning. The writer should present all sides of the argument, but must be able to communicate clearly and without equivocation why a certain position is correct.

As mentioned above there are four types of essay writing. The first type is narrative essay and it tells a story about a real-life experience. The second type is descriptive essay and it paints a picture using words. The third type is expository essay and it is an informative piece of writing that includes different essay varieties, such as the comparison and contrast essay, and the cause and effect essay. The last type is persuasive essay and it is to convince the reader to accept the writer's point of view or recommendation.

\section{Essay Writing Traits:}

According to Klimova (2011, p.393), there are five traits of essay writing that should be considered in writing text. They are as follows:

1. Organizing Ideas:

Ideas are the most important factors in writing because nobody can write meaningfully if she/he does not have anything in mind yet. In a composition class, topic is often given in order to help students concentrate in a certain set of ideas to be explained. For example, the ideas are arranged in order of time, in order of space and in a logical order.

2. Grammar

The grammar of language is a description of way that the language behaves. Without having knowledge of grammar the writer 
cannot make his/her language communicative to a great variety of readers from different situations.

3. Vocabulary

Vocabulary is important in writing because by having many vocabularies a writer can make readers explore more deeply in what he/she is telling about. Having a good vocabulary which is known as idiom gives literary or cultural values to any composition.

4. Mechanics

- Punctuation plays an important role in helping reader to establish intonation. In other words, punctuation is a command for the reader to raise his/her voice or drop his/her speech and because he/she is going to stop. Punctuation can also help readers to understand the state of mind of the writer.

- Capitalization

5. Content

Content is how the writer develops his/her idea related with the topic.

\section{Parts of an Essay:}

According to Howe (2010, pp.83-87) a good essay has three parts:

1. The introduction is the first paragraph of the essay. It should capture the reader's attention and create the desire to read the essay and develop the basic ideas of what you will cover. It should start with a general discussion of your subject to provide background information. These are called general statements. The general statements should lead to the specific statement of your main idea or thesis. This is called the thesis statement. It should be the last sentence of the introduction and is usually only one sentence. It is made up of the topic, focus and three main points of the essay.

2. Each body paragraph should start with a transition - either a word or phrase, like "first", or "another important point is", for example. Then, the first sentence should continue with your topic sentence. The topic sentence tells your reader what the 
paragraph is about, like a smaller-level thesis statement. The rest of the paragraph will be made of supporting sentences. These sentences, at least four of them, will explain your topic sentence to your reader.

3. The conclusion is the last paragraph of the essay. This paragraph brings the essay to a close, reminds the reader of the basic ideas from the essay and restates the thesis statement. It can also contain words of advice or recommendation. The conclusion should not contain new ideas as it is the end of the content of the essay.

\section{There are some studies focused on developing essay writing in English as a foreign language such as:}

- Ahmed (2010) examined students' cohesion and coherence problems in EFL essay writing. A mixed method research design was used including a questionnaire and a semi-structured indepth interview. Analysis of findings revealed that students encounter some problems in the cohesion and coherence of EFL essay writing.

- Alodwan and Ibnian (2014) explored the effect of using the process approach to writing on developing university students' essay writing skills. Results of the study showed that the process approach to writing had positively affected the students' essay writing skills in EFL. Based on results of the study, the researchers recommended placing more emphasis on teaching writing as a process not only as a product.

- Afifi, seleim and Michel (2016) investigated the effect of using of mind mapping on developing essay writing organization skills for 4th year students English section, 6th October University. The findings indicated that there is improvement of 4th year students in essay writing organization skills through using mind mapping. 


\section{Third Section: Attitude towards Writing:}

\section{The Importance of Positive Attitude towards Writing}

Writing is often a challenging skill for learners. To help learners develop their writing skills, teachers employ a variety of techniques for learners to learn and use when writing. However, teachers must investigate further to understand and learn about their learners' attitudes towards writing. This should be done because attitude is an important factor that plays a great part in students' literacy learning. Attitude affects motivation to learn and write and influences how learners approach the writing task. Attitudes are based on self-efficacy beliefs, and that is important to understand as well. (Hanane, 2015, p. 21)

Also, Graham (2006, p.457) stated that a learner who has a positive writing attitude is more likely to plan writing actions, be more effortful, continue despite challenges, set goals that will challenge him or herself, and believe in his or her own success.

Moreover, learners with a more positive attitude will write more often than those with a more negative attitude. Further, those learners with positive attitudes may decide to write even if they are not required to write. Learners with negative attitudes, though, may choose to avoid writing tasks and put forth little effort when writing (Graham et al., 2007, p.516).

Furthermore, Dhadhodara and Joshi (2017, p.111) revealed that writing attitude is a significant part in forming our view towards writing skill. Writing attitude is highly effective on improving or hindering writing achievement. Learners with positive attitudes performed significantly better than those with negative attitudes on writing task. Writing attitude affects writing quality. 
الجزء الاول ابريل

From what is mentioned above it is clear that positive attitude toward writing is very necessary to improve writing skills. Also, negative attitude toward writing can make writing more challenging task. Therefore, understanding attitude and its effect on developing successful writers is vital for guiding writing instruction. If instructors understand learners' attitudes towards writing, this knowledge can impact their instructional practices positively.

\section{Writing Attitude Components}

Hegar (2012, p.99) indicated that attitude has three components. They are as follows:

1. The cognitive component of attitudes refers to learners' beliefs, thoughts, and attributes to knowledge and topics they are exposed to, along with their ability to comprehend, apply, evaluate, and connect the new knowledge with that they already possess.

2. The affective component is the emotional or feeling part of an attitude. It is related to the statement which affects another person. It deals with feelings or emotions that are brought to the surface about something, such as fear or hate.

3. The behavioural component of an attitude consists of a person's tendencies to act in a specific way toward an object. It refers to that part of attitude which reflects the intention of a person in the short-run or long run.

\section{Factors that Affect Attitude towards Writing}

Various factors were found to affect learners' attitude toward writing. For example, the feedback that instructors provide to learners plays a vital role in their attitudes towards writing. Also, students' review of their instructors' notes about writing is very necessary in shaping their attitude toward writing. (Montgomery \& Baker, 2007, p.92) 
Also, teaching methods and learning strategies have a significant role in defining learners' attitude towards writing. For every writing instructor, the goal of instruction is helping learners become knowledgeable writers. The instructors' effort to achieve this aim may be done by employing unsuitable teaching strategies which in turn may lead to learners' development of negative attitudes. (Okasha and Hamdi, 2014, p. 676)

\section{Improving Attitude towards Writing}

Instructors have the primary role in developing learners' writing skills and developing their positive attitudes towards writing. They may help the learners to improve their writing skills and attitudes towards writing through the appropriate learning and teaching processes. However, instructors should have developed good writing skills and positive writing attitudes in order to provide such processes. That is because their own writing skills, their perspectives regarding the process of writing and their writing attitudes significantly affect the writing activities. (Bruning and Horn, 2000, p.25)

Also, Kirmizi (2008, p.95) stated that various methods and techniques should be employed to help the learners develop positive attitudes towards writing. Such methods and techniques are learnercentred, creative and enjoying.

\section{There are some studies focused on developing attitude towards writing in English such as:}

- Ibrahim (2006) examined the effect of using the reading for writing approach on developing the writing ability of Egyptian EFL learners and their attitudes towards writing. The study verified the efficacy of the reading for writing approach as a possible tool for enhancing the writing ability of Egyptian EFL learners and their attitudes towards writing. 
عدد ابريل

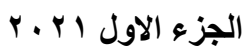

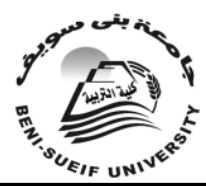

جامعة بني سويف

- Lan, Hung, and Hsu (2011) tried to develop different guided writing strategies based on media richness theory and further evaluate the effects of these writing strategies on younger students' writing attitudes. The findings of this study showed the rich media guided writing strategy had higher significant differences than the pen-and-paper guided writing strategy on students' writing attitudes.

- Elashri (2013) conducted a study to develop some writing skills for second year secondary stage students and their attitudes towards writing through using the genre based approach. The results of this study provided evidence for the effectiveness of using genre-based approach in developing students' writing performance and attitudes towards writing.

- Okasha and Hamdi (2014) conducted a study to investigate the effectiveness of the strategic writing techniques for promoting EFL writing skills and changing passive attitudes towards writing into positive ones. Results of the study revealed that EFL writing skills and attitudes improved among experimental group students as a result of using strategic writing techniques.

\section{Methodology}

\section{Participants of the Research}

The participants of the present research consisted of eighty $1^{\text {st }}$ year English language division students at Cairo Higher Institute for Languages and Interpretation during the second semester of the academic year 2018-2019.

\section{Design of the Research}

The quasi-experimental design was employed in the present research. Eighty students were randomly selected to represent the 
experimental and the control groups. The experimental group pre/posttest design was used to investigate the effect of using the flipped classroom on developing EFL essay writing skills and attitude towards writing among $1^{\text {st }}$ year English language division students at Cairo Higher Institute for Languages and Interpretation. On the other hand, the control group students received regular instruction. Furthermore, a pre-/post- essay writing skills test and a writing attitude scale were given to the two groups before and after the experiment.

\section{The Essay Writing Skills Checklist \\ Purpose of the Checklist}

The checklist was designed by the researcher to determine the most important essay writing traits and skills required for $1^{\text {st }}$ year English language division students at Cairo Higher Institute for Languages and Interpretation.

\section{Sources of the Checklist}

The essay writing traits and skills included in the checklist in its primary form were determined through reviewing a number of related studies focusing on developing essay writing traits and skills. Also, theoretical backgrounds of some studies concerned with essay writing classifications and developing its skills were examined; Smith (2003); Bae and Bachman (2010); Ahmed (2010); and Ariyanti and Fitriana (2017).

\section{Content of the Checklist}

The checklist in its primary form included 5 essay writing traits including 20 skills (see Appendix I). These traits and skills had to be rated by a panel of jury according to a rating scale containing three levels; very important, important, and less important. Each level of importance was given an estimated value to be scored by the researcher, i.e. very important $=3$, important $=2$, and less important $=$ 1.

\section{Validity of the Checklist}

The checklist was submitted to a panel of jury specialized in the field of curriculum and methods of teaching EFL to determine (a) the 
عدد (بريل

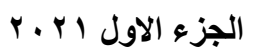

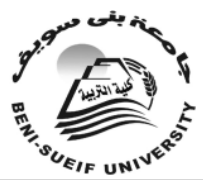

جامعة بني سويفة

degree of importance of each skill to the sample of the research and (b) suitability of the skill to the level of $1^{\text {st }}$ year language institutes students (c) relatedness of the skill to the traits of essay writing. The jury was composed of (4) specialists in the field of TEFL and methods of teaching and (1) specialist in the field of teaching German as foreign languages. (See Appendix VI)

The following modifications were carried out as suggested by the panel of jury:

1. Confining the research to four traits and nineteen essay writing skills to be the necessary for $1^{\text {st }}$ year language institutes students' level as agreed upon by $80 \%$ of the jury members to be most important.

2. Omitting the skills "Evading double negatives in an essay", "Avoiding dangling / misplaced modifiers in an essay", and "Avoiding "its" and "it's" confusion in an essay".

3. Dividing the organization skill "Writing an effective introduction, body paragraphs, and a concluding paragraph" to be three separate skills; namely, "Writing an effective introduction for an essay", Developing effective body paragraphs that contain one central idea, and enough supporting details and examples", and "Writing an effective concluding paragraph".

4. Arranging the chosen traits and skills logically.

5. Combining the organization skills and sentence fluency skills.

So, as the jury indicated, the checklist became valid and the traits and skills included became adequate and clear. After analyzing the jury responses, the researcher selected those skills that were agreed upon by at least $80 \%$ or more by the jury members to be the most necessary skills that $1^{\text {st }}$ year language institutes students require. Thus, the first question of the present research was answered. (The checklist in its primary and final forms and the names of the panel of jury are in appendices (I) and (VI). 


\section{Measurement Instruments of the Research}

The researcher designed the following three instruments:

1. A pre/post- essay writing performance test.

2. An analytic essay writing scoring rubric.

3. A writing attitude scale.

Each of the above instruments are tackled in details below:

\section{a) The Essay Writing Performance Test}

\section{Aim of the Test}

The pre-/post- essay writing test aimed at measuring the essay writing skills of the research subjects. It was constructed to be administered to the two groups of the present research twice: first, prior to the experiment as a pre-test and to make sure that the students of both groups were at the same level before starting the treatment. Hence, the progress achieved by the experimental group could be attributed to the flipped classroom. Second, it was to be used as a posttest, to compare its scores with those of the pre-test to investigate the effect of the flipped classroom on developing the experimental group students' essay writing skills.

\section{Construction of the Test}

The test was constructed by the researcher after reviewing the following sources:

- Previous studies concerned with language tests, especially those that are concerned with developing essay writing skills.

- Identifying the skills to be measured by the test through the final form of the checklist. (See appendix I for the final form of the essay writing skills checklist).

\section{Description of the Test}

The final form of the test was 3 main questions; the first question was designed for testing students' performance on grammar, the second question was designed for testing students' performance on word 
عدد ابريل

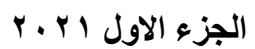

choice, and the third question was designed for testing students' performance on mechanics, organization and sentence fluency skills. The final version of the test is shown in Appendix (II).

\section{Validity of the Test}

To find out whether or not the pre/post- test was valid for what it was intended to measure, the researcher depended upon two aspects of validity. The first one was the content validity; the first form of the test was given to 5 TEFL specialists to evaluate each question in terms of content and level of essay writing skills measured. Besides, they were asked to evaluate the test as a whole in terms of: correctness and number of questions. The second aspect of validity was the experimental validity which was calculated by the square root of the reliability coefficient.

\section{Content Validity}

To determine content validity of the test, a criteria questionnaire developed by the researcher kindly asked 5 TEFL specialists to validate the test. The test proved to be mostly valid as the jury approved most of the questions and suggested the following:

1. Using simpler test instructions that may not confuse the students.

2. Adding two other questions because asking students only one question is not enough to measure all required skills.

\section{Experimental Validity}

The researcher computed experimental validity of the test statistically using the following formula.

Test validity $=\sqrt{\text { reliability coefficient }}$

Validity $=\sqrt{(0.93)}$

Validity $=0.927$

This proved that the essay writing performance test was statistically valid.

\section{Piloting the Test}

The pre/post- essay writing performance test was piloted on (30) $1^{\text {st }}$ year English language division students at Cairo Higher Institutes, other than the subjects of the research. To test its reliability, the test was administered to them twice and the time between the two administrations was two weeks to ensure that they would not be able to 


$$
\begin{aligned}
& \text { عداد ابريل }
\end{aligned}
$$

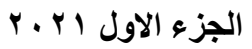
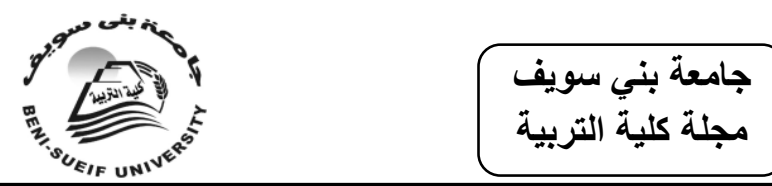

remember their answers in the first administration. So, the pilot study of the test aimed at the following:

- Estimating the timing for the test.

- Testing the clarity of the test directions and identifying the questions that might be misunderstood to be modified.

- Establishing the reliability of the test.

\section{Results of Piloting the Test}

\section{- Estimating the time for the test}

It was decided that a period of 120 minutes would provide ample time for the students to answer the test questions. As the group used to calculate reliability of the test was the same group used to estimate the test time, each student was required to write down on his/her exam paper the time taken for answering the test exactly. Then, the test time was estimated in the following way:

Summation of the time taken by all students

\section{Number of students}

\section{So, test time $=1$ ro minutes}

\section{- Establishing the reliability of the test}

In order to establish the reliability of the pre/post- essay writing performance test, the following methods were used:

\section{- Interrater reliability}

The answers of the group of (30) students mentioned in piloting the test were evaluated by two independent raters. Using Pearson's coefficient correlation between the first and the second rater's estimations, it was found that the correlation coefficient was $(r=0.89)$ which is significant at the level 0.01 .

\section{- Test-retest reliability}

The two administrations of the test to the (30) students were correlated using Pearson's coefficient correlation. The correlation for the pre-test was $(r=0.9)$ and for the post-test was $(r=0.87)$, which are significant at the 0.01 level. 


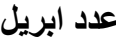

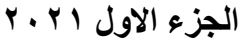

Based on the above calculations, it could be said that the pre/post- essay writing performance test had high interrater reliability and test-retest reliability.

\section{b) Essay Writing Skills Scoring Rubric}

\section{Aim of the Rubric}

In order to evaluate the essay writing traits of the sample of the research, the researcher devised an essay writing skills scoring rubric as a pre-post measuring instrument. It measured the essay writing skills required for the participants. It was submitted to jury members specialized in the field of methods of teaching English to test the validity and appropriateness. Having done their modifications, the rubric became valid. The essay writing skills scoring rubric is shown in Appendix (III).

\section{Constructing the Rubric}

The following procedures were followed in constructing the essay writing skills analytic scoring rubric:

1. Reviewing literature and previous studies that dealt with performance assessment and designing rubrics.

2. Designing the rubric which included the mechanics, organization and sentence fluency skills:

a. Applying basic rules of capitalization correctly.

b. Using accurate punctuation.

c. Using spelling properly.

d. Organizing the essay to include an introductory paragraph, body paragraphs, and a concluding paragraph.

e. Writing an effective introduction for an essay.

f. Developing effective body paragraphs that contain one central idea, and enough supporting details and examples.

g. Writing an effective concluding paragraph.

h. Establish unity for an essay 
i. Establish coherence for an essay

j. Avoiding sentence fragments

$\mathrm{k}$. Avoiding run-on sentences.

1. Using a variety of sentence types (simple sentences, compound sentences and complex sentences).

3. Distributing the scores of the mechanics, organization and sentence fluency traits upon its skills. Each skill included 4 levels: strong (4 scores), effective (3 scores), progressing (2 scores), and developing (1 score).

4. Certifying the validity and reliability of the rubric.

5. Writing and revising the final form of the rubric.

6. The second rater's training on how to use the rubric.

\section{Validity of Essay Writing Skills Analytic Rubric}

To find out whether or not the rubric was valid for what it was intended to measure, the researcher submitted the first form of the rubric to 5 TEFL experts to evaluate it; in terms of content and level of the skills measured. Submitting the rubric to the jury members resulted in modifying it according to their suggestions. For the final form of the rubric and the criteria of judging it, see appendix III.

\section{Reliability of Essay Writing Skills Analytic Rubric}

To measure the reliability of the essay writing skills analytic scoring rubric, it was administered twice to (30) students and evaluated by two raters. Then, the Pearson correlation formula was used to calculate the correlation between the two administrations which is ( $\mathrm{r}$ $=0.91$ ), significant at the level 0.01. Thus, the rubric was considered reliable.

\section{c) Attitude towards Writing Scale}

A pre-/post- writing attitude scale was constructed to be administered to the two groups of the experiment. It was used prior to the experiment to make sure that students of both groups have the same writing attitude before starting the experiment, and therefore the 
عدد (بريل

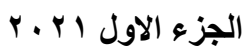

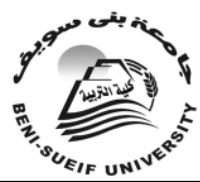

جامعة بني سويفة التربية

progress achieved by the experimental group in its post-administration to both groups could be attributed to the suggested framework they have been taught. So, it was constructed to be used to investigate the effect of flipped classroom on developing attitude towards writing for $1^{\text {st }}$ year English language division students at Cairo Higher Institutes.

The scale is consisted of 30 items and each item has a five-pointLikert format: (5) Strongly Agree (SA), (4) Agree (A), (3) Uncertain (U), (2) Disagree (D), and (1) Strongly Disagree (SD). Responses from the subjects of the experimental group were collected online through the Google Classroom Platform. The scale was made available for students' participation for a period of two days, after which students were no longer able to use the link provided.

\section{Sources of the Scale Items}

The review of related literature and studies that dealt with attitude towards writing such as Ibrahim (2006), Lan et al., (2011), Elashri (2013), and Hamdi (2014).

\section{Constructing the Writing Attitude Scale}

The following procedures were followed in constructing the writing attitude scale:

1. Reviewing literature and previous studies that dealt with writing attitude scales.

2. Designing the writing attitude scale which includes 33 statements.

3. Submitting the writing attitude scale in its primary form to the jury members.

The following points were taken into account when writing the scale items:

- Two statements were modified.

- Three statements were omitted. 
Table (1): Statements of the writing attitude scale before and after modification

\begin{tabular}{|l|l|}
\hline \multicolumn{1}{|c|}{ Statement before modification } & \multicolumn{1}{c|}{ Statement after modification } \\
\hline Writing is a very important skill. & $\begin{array}{l}\text { Writing in English is a very important skill to } \\
\text { me. }\end{array}$ \\
\hline I am interested in writing in English. & $\begin{array}{l}\text { I am interested in writing in English most of the } \\
\text { time. }\end{array}$ \\
\hline
\end{tabular}

Table (2): Statements of the writing attitude scale being omitted

\begin{tabular}{|c|l|}
\hline 5 & I feel that writing in English provides me with communication skills. \\
\hline 29 & I often feel nervous when I have a lot of writing to do. \\
\hline 32 & I need a lot of assist in writing in English. \\
\hline
\end{tabular}

4. Certifying the validity and reliability of the writing attitude scale.

5. Writing and revising the final form of the writing attitude scale.

\section{Validity of the Writing Attitude Scale}

The writing attitude scale was submitted to 5 jury members. The jurors were kindly asked to provide their opinions in terms of the following:

1. The extent to which the writing attitude scale is suitable for application.

2. Deciding whether some statements need to be modified, added, or omitted.

Suggestions were provided, modifications were made, and the scale in its final form contained 30 statements and was valid and suitable for application. For the final form of the writing attitude scale and the criteria of judging it, see appendix IV.

\section{Reliability of the Writing Attitude Scale}

To estimate the reliability of the writing attitude scale, it was administered to 30 students, other than the present research subjects, and after 15 days the writing attitude scale was re-administered again to the same sample. Pearson correlation formula was used to calculate 
عدد ابريل

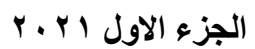

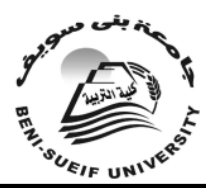

جامعة بني سويف كلية التربية

the correlation between the two administrations which is $(\mathrm{r}=0.91)$, significant at the level 0.01. Thus, the writing attitude scale was considered reliable.

\section{Formation of the Writing Attitude Scale Items}

The total number of the writing attitude scale statements was 30 . The writing attitude scale was written in a table format. Likert fiveresponses scale; namely, strongly disagree (1), disagree (2), uncertain (3), agree (4) and strongly agree (5) was used for eliciting the participants' responses. For details, see appendix IV.

\section{The Suggested Steps for Using the Proposed Framework}

\section{a) Objectives of the proposed framework}

The main aim of the proposed framework was developing the EFL essay writing skills most necessary for $1^{\text {st }}$ year students at Cairo Higher Institute for Languages and Interpretation. The researcher used diversity of activities and tasks through the sessions to enable the participants accomplish the objectives of the proposed framework.

\section{b) Description and Framework of Using Flipped Classroom}

The proposed framework consisted of 16 sessions. The first session was an introductory session about flipped classroom and tools used in the sessions, the sub-skills of EFL essay writing skills and the importance of these skills to the research sample. The rest sessions were instructional ones through which the EFL essay writing skills were practiced (grammar, mechanics, word choice, organization and sentence fluency). (See Appendix V).

c) Implementation of the proposed framework Using Flipped Classroom 
In conducting, this research using the flipped classroom, the following procedures were followed:

1. The researcher prepared the educational videos and the instructional writing tasks which are based on the course "Essay Writing".

2. The researcher used Google site to create Google Classroom Platform.

3. The educational videos were recorded and uploaded onto the Google Classroom Platform for students in the experimental group to access to them prior to the lessons.

4. The website was used as a teaching and learning tool for the essay writing skills lessons and tasks. The researcher considered the students' levels and abilities.

5. The content of the website was selected and arranged according to students' achievement goals.

6. At the introductory stage, the students were informed the purpose of sessions as part of assessment of their performance in EFL essay writing skills that should be using flipped classroom. They were also informed the meaning and purpose of flipped classroom and Google Classroom implementation. The preparation stage starts from the previous meeting. First, the lecturer informed the students that they will use the Google Classroom Platform at home after adding them to the site and the instructor send them code for access this site.

7. The second stage involved training the learners on how to use Google Classroom Platform to watch videos at home.

8. The researcher added related activities and quizzes to each lesson and asked students to answer and post them.

9. The content of the website could be watched online or downloaded on their own computers or mobile-phones.

10.The website was student-centered, and the teacher was a facilitator, guide and director. The researcher can chat with students and students could chat with each other. 
عدد ابريل

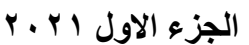

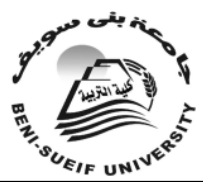

جامعة بني سويف

11.The researcher taught the students how to watch and interact with the videos. The researcher set up the classroom to suit flipped learning environment.

12.The researcher employed student-centered as well as cooperative and collaborative learning. Students were allowed to work in pairs.

13.The researcher encouraged students to help each other. The researcher moved around the students to follow up students' work.

14.The participants were provided with immediate feedback from the researcher and their classmates.

15.In the end, the researcher implemented the essay writing posttest to explore the progress in students' performance after intervention.

\section{Phases of the Framework Sessions}

During the sessions of the framework the following main flipped classroom procedures and phases were used:

\section{A. Warm-up:}

- The instructor began every session by asking students a question to check what had been learned in the study of teaching materials (online videos).

\section{B. Teaching Steps:}

- Teaching using flipped classroom is divided into three main phases. These phases are as follows:

1. Pre-class/Before Class Phase: This phase is named "Watch and Question"

Students watch the online instructional video and take written notes of the video.

At the end of the video, they will be given some questions to answer.

All students are required to ask a question about what they watched at the end of the video. 
Students can prepare questions for the teacher.

Students can have group discussion through the Google Classroom Platform.

\section{In Class Phase:}

* The teacher starts providing opportunities to discuss, review, and analyze students' notes and summaries from the video.

Students start working in small groups or individually to complete several activities and tasks inside the classroom.

Students share notes and summaries of the video reviewed at home.

Students use individual questions from the homework questions in groups.

Students incorporate the main points and produce a group response to each question.

\section{After Class/ Post Class Phase:}

\# The teacher traces students' learning by keeping a record of students' performance in any assignments and tasks.

Google Classroom offers an assessment platform where the teacher can monitor students' learning online with the data collected regarding the students' learning activities in this platform.

In addition, instead of relying on exams to assess students' academic achievement, the teacher adopts a multidimensional way of assessing students' learning, which may include selfevaluation, peer evaluation, and the teacher's evaluation.

\section{Home Assignment:}

Each session will end with assigning two assignments. They are as follows:

\section{Assignment (1)}

Students will have some questions on Google Classroom Platform. They have to answer these questions.

These questions will be corrected by the instructor to receive feedback.

\section{Assignment (2)}


عدد ابريل

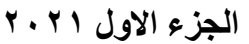

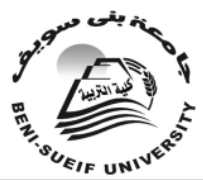

جلة كلية بني سويف

Students have to watch an online video on Google Classroom Platform at home.

Take notes on the online video in their notebooks.

Answer the given questions about the content of the video.

\section{Groups Equivalence}

The main purpose of the present research was to develop most necessary essay writing skills and attitude towards writing in English for $1^{\text {st }}$ year Cairo Higher Institute for Languages and Interpretation students throughout using flipped classroom. So, before implementing the suggested lessons with those students, an essay writing skills test was pre-administered to both the control and the experimental groups of the research.

The following table shows that there was no statistically significant difference between the mean scores of the control and the experimental groups on the pre-administration of the test in the essay writing skills.

Table (3): " $t$ " value of the difference between the mean scores of the experimental and control groups' students on the preadministration of the essay writing skills test

\begin{tabular}{|c|c|c|c|c|c|c|c|}
\hline Group & $\mathbf{N}$ & $\begin{array}{c}\text { Mea } \\
\text { n }\end{array}$ & $\begin{array}{c}\text { Std. } \\
\text { Deviation }\end{array}$ & D.F. & $\begin{array}{c}\text { Calculated } \\
\text { t-value }\end{array}$ & $\begin{array}{c}\text { Tabulated } \\
\mathbf{T}\end{array}$ & Sig. \\
\hline Control & 40 & 17.85 & 6.121 & \multirow[t]{2}{*}{78} & \multirow[t]{2}{*}{0.018} & \multirow{2}{*}{$r .0$} & \multirow{2}{*}{$\begin{array}{l}\text { Non } \\
\text { Significant } \\
\text { at } 0.05\end{array}$} \\
\hline $\begin{array}{c}\text { Experiment } \\
\text { al }\end{array}$ & 40 & 17.83 & 6.210 & & & & \\
\hline
\end{tabular}

From table (3), the " $\mathrm{t}$ " calculated value (0.018) was lower than the tabled $T$ value $(r . \cdot 0)$ with (78) degrees of freedom at the (0.05) level of significance. Thus, there was no statistically significant difference between the experimental group students and the control group students' mean scores on the pre-administration of the essay writing 
skills test. This proves that the two groups were almost at the same level of essay writing skills before conducting the experiment.

Also, before implementing the suggested lessons with those students, a writing attitude scale was pre-administered to both the control and the experimental groups of the research.

The following table shows that there was no statistically significant difference between the mean scores of the control and the experimental groups on the pre-administration of the writing attitude scale.

Table (4): " $t$ " value of the difference between the mean scores of the experimental and control groups' students on the preadministration of the writing attitude scale.

\begin{tabular}{|c|c|c|c|c|c|c|c|}
\hline Group & $\mathbf{N}$ & Mean & $\begin{array}{c}\text { Std. } \\
\text { Deviation }\end{array}$ & $\begin{array}{l}\text { D.F } \\
\text {. }\end{array}$ & $\begin{array}{l}\text { Calculate } \\
\text { d t-value }\end{array}$ & $\begin{array}{c}\text { Tabulate } \\
\text { d T }\end{array}$ & Sig. \\
\hline Control & 40 & 51.08 & 10.027 & \multirow[t]{2}{*}{78} & \multirow[t]{2}{*}{0.100} & \multirow[t]{2}{*}{$r .0$} & \multirow{2}{*}{$\begin{array}{c}\text { Non } \\
\text { Significant } \\
\text { at } 0.05\end{array}$} \\
\hline $\begin{array}{l}\text { Experiment } \\
\text { al }\end{array}$ & 40 & 50.85 & 10.078 & & & & \\
\hline
\end{tabular}

From table (4), the " $t$ " calculated value $(0.100)$ was lower than the tabled T value (2.00) with (78) degrees of freedom at the (0.05) level of significance. Thus, there was no statistically significant difference between the experimental group students and the control group students' mean scores on the pre-administration of the writing attitude scale. This proves that the two groups were almost at the same level of the writing attitude before conducting the experiment.

\section{Data Analysis and Results}

The results of the research are discussed and interpreted in relation to the research questions and hypotheses mentioned earlier as follows:

\section{1-Answering the first sub- question}




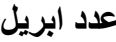

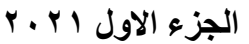

To identify the required essay writing skills for $1^{\text {st }}$ Cairo Higher Institute for Languages and Interpretation students, a checklist was designed by the researcher. The checklist was submitted to five jury members and they approved it. It included nineteen skills in its final version (see appendix 1). Thus, the first sub- question of the present research was answered.

\section{2-Answering the second sub-question}

The second sub- question was answered before as the suggested steps for using the proposed framework of using flipped classroom as were shown before in the preceding pages. For more details, the proposed framework of the present research as a whole is shown in appendix V.

\section{3-Answering the third sub-question}

Answering the third sub-question is related to verifying the hypotheses of the present research. So, they will be dealt together as follows:

\section{A-Findings related to the first hypothesis}

The first hypothesis stated that: "There is a statistically significant difference between the experimental group and the control group students' mean scores on the post-administration of the essay writing skills test in favour of the experimental group".

The essay writing skills test was administered to the control and experimental groups after the experiment. Data obtained were treated statistically. Findings are shown in table (5)

Table (5): "t" Value of the Difference Between the Mean Scores of the Experimental and Control Groups' Students on the PostAdministration of the Test 


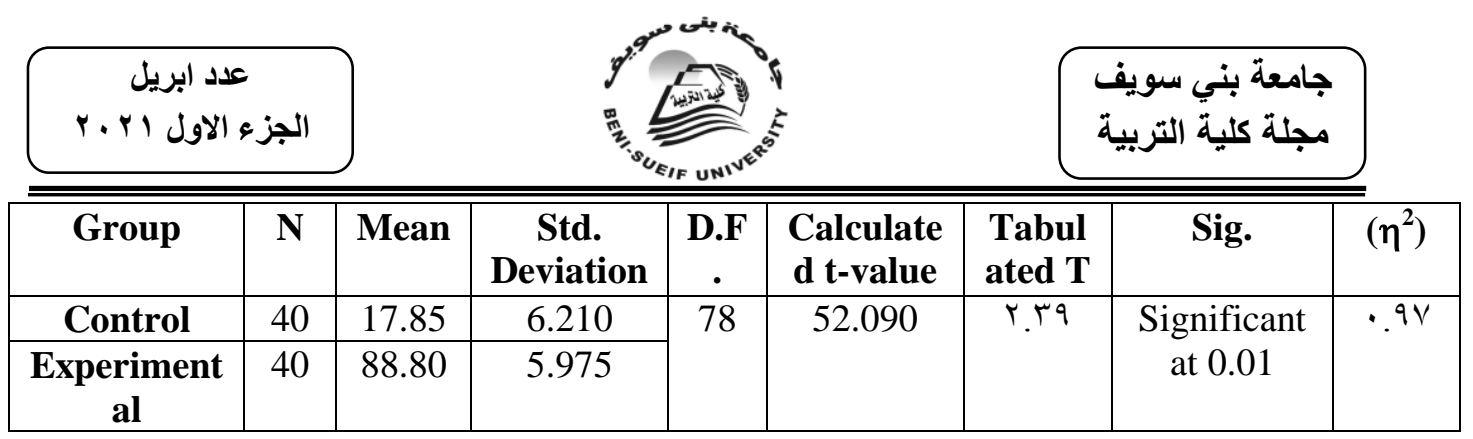

The above table (5) confirms the following:

1. It was proved that the experimental group students' mean score (88.80) was higher than the mean score of the control group students (17.83) on the post-administration of the essay writing test. This is a highly significant difference which showed that the experimental group students attained remarkable higher scores than the control group students in the post-test. Therefore, development of the experimental group students' essay writing skills was due to the proposed framework using flipped classroom.

2. The " $t$ " calculated value (52.090) was significantly higher than the $T$ tabled value ( $r . \mathrm{q}$ ) with (78) degrees of freedom at the (0.01) level of significance. Thus, there was a statistically significant difference between the experimental and the control group students' mean scores on the post-administration of the essay writing test in favour of the experimental group students. Thus, the first hypothesis of the research was verified.

3. The effect size of using flipped classroom on developing essay writing skills for the first year university students was calculated and the result was (0.97) as shown in the above table (5) and this showed that using flipped classroom had a large effect on developing students' essay writing skills. Thus, the third question of the present research which is " What is the effect of using flipped classroom on developing the most necessary EFL essay writing skills of the $1^{\text {st }}$ year students of Cairo Higher Institute for Languages and Interpretation? was answered.

\section{B-Findings related to the second hypothesis}

The second hypothesis stated that: "There is a statistically significant difference between the experimental group's mean scores 
عدد ابريل

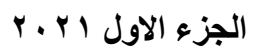

on the pre and post-administrations of the essay writing skills test in favour of the post-administration of the test."

The essay writing skills test was administered to the experimental groups before and after the experiment. Data obtained were treated statistically. Findings are shown in table (6).

Table (6): "t" Value of the Difference Between the Mean Scores of the Experimental Group Students on the Pre and PostAdministrations of the Test

\begin{tabular}{|c|c|c|c|c|c|c|c|c|}
\hline $\begin{array}{c}\text { Experim } \\
\text { ental }\end{array}$ & $\mathbf{N}$ & $\begin{array}{c}\text { Mea } \\
\text { n }\end{array}$ & $\begin{array}{c}\text { Std. } \\
\text { Deviation }\end{array}$ & $\begin{array}{l}\text { D. } \\
\text { F. }\end{array}$ & $\begin{array}{l}\text { Calculate } \\
\text { d t-value }\end{array}$ & $\begin{array}{c}\text { Tabulated } \\
\mathbf{T}\end{array}$ & Sig. & $\left(\eta^{2}\right)$ \\
\hline Pre & 40 & 17.83 & 6.210 & \multirow[t]{2}{*}{39} & \multirow[t]{2}{*}{157.455} & \multirow[t]{2}{*}{ T.EYT } & \multirow{2}{*}{$\begin{array}{c}\text { Significan } \\
\mathrm{t} \\
\text { at } 0.01\end{array}$} & \multirow[t]{2}{*}{0.99} \\
\hline Post & 40 & 88.80 & 5.975 & & & & & \\
\hline
\end{tabular}

The above table (6) confirms the following:

1. It was proved that the experimental group students' mean score (88.80) was higher than the mean score of the control group students (17.83) on the post-administration of the essay writing test. This is a highly significant difference which showed that the experimental group students attained remarkable higher scores than the control group students in the post-test. Therefore, development of the experimental group students' essay writing skills was due to the proposed framework using flipped classroom.

2. The "t" calculated value (157.455) was significantly higher than the $T$ tabled value ( $r . \Sigma r r$ ) with (39) degrees of freedom at the (0.01) level of significance. Thus, there was a statistically significant difference between the experimental and the control group students' mean scores on the post-administration of the essay writing test in favour of the experimental group students. Thus, the second hypothesis of the research was verified.

3. The effect size of using flipped classroom on developing essay writing skills for the first year university students was calculated 
and the result was (0.99) as shown in the above table (6) and this showed that using flipped classroom had a large effect on developing students' essay writing skills. Thus, the third question of the present research which is " What is the effect of using flipped classroom on developing the most necessary EFL essay writing skills of the $1^{\text {st }}$ year students of Cairo Higher Institute for Languages and Interpretation? was answered.

\section{C-Findings related to the third hypothesis}

The third hypothesis stated: "There is a statistically significant difference between the experimental group students' mean scores in each essay writing trait on the pre and post-administrations of the essay writing skills test in favour of the post-administration."

In order to verify this hypothesis, the mean scores of the experimental group in each essay writing trait on the pre and postadministrations of the essay writing skills performance test were calculated.

Table (7): The Mean Scores in Each Essay Writing Trait on the Pre and Post-Administrations of the Essay Writing Performance Test and Effect Size on Each Trait

\begin{tabular}{|c|c|c|c|c|c|c|c|c|}
\hline Trait & Test & $\mathbf{N}$ & Mean & $\begin{array}{l}\text { Std. D } \\
\end{array}$ & $\begin{array}{c}\text { The } \\
\text { calculate } \\
\text { d t }\end{array}$ & $\begin{array}{l}\text { The } \\
\text { tabulated } \\
\text { T }\end{array}$ & D.F. & Sig. \\
\hline \multirow{2}{*}{$\begin{array}{l}\text { Gramma } \\
\text { r }\end{array}$} & Pre & 40 & 4.60 & 1.676 & \multirow[t]{2}{*}{79.113} & \multirow[t]{2}{*}{ Y.EYT } & \multirow[t]{2}{*}{39} & \multirow{2}{*}{$\begin{array}{c}\text { Sig. at } \\
0.01\end{array}$} \\
\hline & Post & 40 & 17.75 & 1.276 & & & & \\
\hline \multirow{2}{*}{$\begin{array}{l}\text { Mechanic } \\
\text { s }\end{array}$} & Pre & 40 & 3.18 & 1.723 & \multirow[t]{2}{*}{30.339} & \multirow[t]{2}{*}{ T.EYT } & \multirow[t]{2}{*}{39} & \multirow{2}{*}{$\begin{array}{c}\text { Sig. at } \\
0.01\end{array}$} \\
\hline & Post & 40 & 11.00 & 0.784 & & & & \\
\hline \multirow{2}{*}{$\begin{array}{l}\text { Word } \\
\text { Choice }\end{array}$} & Pre & 40 & 6.65 & 2.007 & \multirow[t]{2}{*}{61.633} & \multirow[t]{2}{*}{$T . \Sigma Y T$} & \multirow[t]{2}{*}{39} & \multirow{2}{*}{$\begin{array}{c}\text { Sig. at } \\
0.01\end{array}$} \\
\hline & Post & 40 & 18.78 & 1.250 & & & & \\
\hline \multirow{2}{*}{$\begin{array}{l}\text { Organiza } \\
\text { tion \& } \\
\text { Sentence } \\
\text { Fluency }\end{array}$} & Pre & 40 & 3.40 & 1.499 & \multirow[t]{2}{*}{82.552} & \multirow[t]{2}{*}{$T . \leqslant Y T$} & \multirow[t]{2}{*}{39} & \multirow{2}{*}{$\begin{array}{c}\text { Sig. at } \\
0.01\end{array}$} \\
\hline & Post & 40 & 41.28 & 3.609 & & & & \\
\hline \multirow{2}{*}{$\begin{array}{l}\text { Test as } \\
\text { whole }\end{array}$} & Pre & 40 & 17.83 & 6.210 & \multirow[t]{2}{*}{157.455} & \multirow[t]{2}{*}{$T . \leqslant Y T$} & \multirow[t]{2}{*}{39} & \multirow{2}{*}{$\begin{array}{c}\text { Sig. at } \\
0.01\end{array}$} \\
\hline & Post & 40 & 88.80 & 5.975 & & & & \\
\hline
\end{tabular}


From the above table (7), it is clear that the " $\mathrm{t}$ " calculated value of each of the four essay writing traits; 79.113, 30.339, 61.633, 82.552 respectively was significantly higher than the $T$ tabled value $(r . \leqslant r T$ ) with (39) degrees of freedom at the (0.01) level of significance. Thus, there was a statistically significant difference between the experimental group students' mean scores of each essay writing trait on the pre and post-administrations of the essay writing skills performance test in favour of the post-administration of the test. Thus, the third hypothesis of the research was verified.

\section{D-Findings related to the fourth hypothesis}

The fourth hypothesis of the research states that "The proposed framework using flipped classroom has a large effect size on developing each essay writing trait". In order to verify this hypothesis, the effect size of the proposed framework on each trait was calculated. Table (8) below reveals that the effect size on each trait is large. Accordingly, the fourth hypothesis was verified and the fifth question of the research was also answered.

\section{Table (8): Value of the Effect Size on Each Trait}

\begin{tabular}{|l|c|c|}
\hline \multicolumn{1}{|c|}{ Trait } & the calculated t & Effect size $\boldsymbol{\eta}^{\mathbf{2}}$ \\
\hline Grammar & 79.113 & 0.99 \\
\cline { 3 - 3 } & & large \\
\hline Mechanics & 30.339 & 0.96 \\
\cline { 3 - 3 } & & large \\
\hline Word Choice & 61.633 & 0.99 \\
\hline Organization \& Sentence Fluency & & large \\
\cline { 3 - 3 } & & 0.99 \\
\cline { 3 - 3 } & & large \\
\hline
\end{tabular}

\section{E-Findings related to the Fifth hypothesis}

The fifth hypothesis stated: "There is a statistically significant difference between the experimental group and the control group students' mean scores on the post-administration of the writing attitude scale in favour of the experimental group." 
The following table shows that there was statistically significant difference between the mean scores of the control and the experimental groups on the pre- administration of the reading attitude scale.

Table (9): "t $t$ " value of the difference between the mean scores of the experimental and control groups' students on the postadministration of the writing attitude scale

\begin{tabular}{|c|c|c|c|c|c|c|c|c|}
\hline Group & $\mathbf{N}$ & Mean & Std. D. & D.F & $\begin{array}{l}\text { Calculated } \\
\text { t-value }\end{array}$ & $\begin{array}{l}\text { Tabul } \\
\text { ated T }\end{array}$ & Sig. & $\left(\eta^{2}\right)$ \\
\hline Control & 40 & 56.58 & 8.935 & \multirow[t]{2}{*}{78} & \multirow[t]{2}{*}{44.897} & \multirow[t]{2}{*}{ r.rq } & \multirow{2}{*}{$\begin{array}{l}\text { Significant } \\
\text { at } 0.01\end{array}$} & \multirow[t]{2}{*}{.97} \\
\hline $\begin{array}{l}\text { Experiment } \\
\text { al }\end{array}$ & 40 & 138.28 & 7.254 & & & & & \\
\hline
\end{tabular}

The above table (9) confirms the following:

1. It was proved that the experimental group students' mean score (138.28) was higher than the mean score of the control group students (56.58) on the post-administration of the writing attitude scale. This is a highly significant difference which showed that the experimental group students attained remarkable higher scores than the control group students in the post-test. Therefore, development of the experimental group students' writing attitude was due to the suggested lessons.

2. The " $t$ " calculated value (44.897) was significantly higher than the $T$ tabled value ( $r .{ }^{r} q$ ) with (78) degrees of freedom at the (0.01) level of significance. Thus, there was a statistically significant difference between the experimental and the control group students' mean scores on the post-administration of the writing attitude scale in favour of the experimental group students. Thus, the fifth hypothesis of the research was verified.

\section{F-Findings related to the sixth hypothesis}

The sixth hypothesis stated: " There is a statistically significant difference between the experimental group's mean scores on the pre 


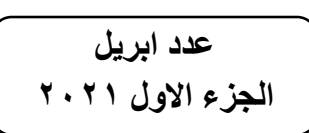

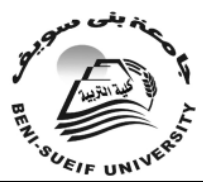

$$
\text { جامعة بني سويف }
$$

and post-administrations of the writing attitude scale in favour of the post-administration ".

Table (10): " $t$ " value of the difference between mean scores of the experimental group students on the pre and post-administrations of the scale for the writing attitude and the effect size of the suggested lessons

\begin{tabular}{|c|c|c|c|c|c|c|c|c|}
\hline Experimental & $\mathbf{N}$ & Mean & $\begin{array}{c}\text { Std. } \\
\text { Deviatio } \\
\mathbf{n}\end{array}$ & $\begin{array}{c}\text { D.F } \\
\cdot\end{array}$ & $\begin{array}{c}\text { Calculated } \\
\text { t-value }\end{array}$ & $\begin{array}{c}\text { Tabula } \\
\text { ted T }\end{array}$ & Sig. & $\left(\boldsymbol{\eta}^{\mathbf{2}}\right)$ \\
\hline Pre-test & 40 & 50.85 & 10.078 & 39 & 134.026 & Y. $\leqslant$ r & Significan \\
$\mathrm{t}$ \\
Post-test & 40 & $\begin{array}{c}138.2 \\
8\end{array}$ & 7.254 & & & $\ddots 99$ \\
at 0.01 & \\
\hline
\end{tabular}

The above table (10) indicates the following:

1. The " $t$ " calculated value (134.026) was significantly higher than the $T$ tabled value $(Y . \leq Y r)$ with (39) degrees of freedom at the (0.01) level of significance. Thus, there was a statistically significant difference between the experimental group students' mean scores on the pre and post-administrations of the writing attitude scale in favour of the post-administration of the test.

2. The mean score of the experimental group students on the writing attitude scale post-administration (138.28) was higher than their mean score on the pre-administration (50.85). Thus, a development of the writing attitude of the experimental group students was proved, due to the suggested lessons. Thus, the sixth hypothesis of the research was verified.

To sum up, support was gained for all the research hypotheses. The experimental group students achieved tangible progress in their essay writing skills and attitude towards writing after using flipped classroom. Consequently, these positive results of the research proved the positive effect of using flipped classroom on developing the EFL essay writing skills and attitude towards writing of the $1^{\text {st }}$ year students of Cairo Higher Institute for Languages and Interpretation. 


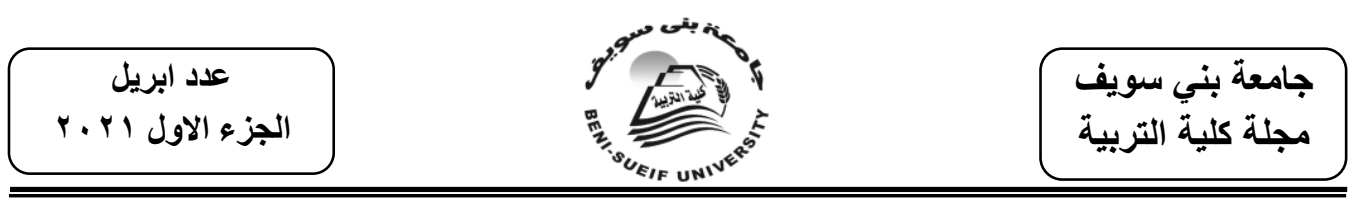

\section{Discussion of results}

The statistical analysis presented above, resulted in the verification of all the hypotheses of the research and answering the research questions. It also realized the achievement of the research main aim, which was to develop the most necessary EFL essay writing skills and attitude towards writing of the $1^{\text {st }}$ year students of Cairo Higher Institute for Languages and Interpretation throughout the use of flipped classroom.

The comparison between the experimental group and the control group showed that the improvement achieved by the experimental group in the required essay writing skills was more than that of the control group in the post tests. The researcher attributed this improvement to the following factors:

1. Providing students with a relaxed non-threatening learning environment and friendly atmosphere through which they were motivated to participate in all tasks. This is consistent with Talbert (2012) and Kim, et.al. (2014) who stressed the importance of providing a welcoming and caring learning environment as one of the main principles for designing effective flipped classroom.

2. Using several online videos and tasks attracted students' attention and interests. They enjoyed using computer and that increased students' engagement and motivated them to write essays. In addition, students received a lot of help from instructor. The responses were always very fast. So, being able to interact with the instructor regularly kept students focused on carrying out the task. This led to increasing their confidence. This is consistent with Finkel (2012) who indicated that the use of flipped classroom gives students opportunity to be taught how to stay attentive, to collaborate with peers, and to be wellorganized.

3. The proposed framework was designed in a cycle form. Each step had its objectives and tasks to be dealt with. It involved the gradual release in flipped steps from learning together to work 
alone. Students began practicing essay writing skills with their instructor in groups. Instructor monitored them till reaching the target aim of the research.

4. Exchanging responses encouraged students to see the other side of each topic and reinforce getting continuous feedback. They were trained on using peer review for feedback. This encouraged them to improve their essay writing skills and attitude towards writing. Developing interaction with students whether inside or outside the classroom, in addition to frequent discussions were permitted with providing opportunities to cooperate and collaborate together. Through online tasks, students communicated and interacted with each other. So, different social relationships were created.

5. Watching online videos on Google Classroom help students to be responsible for their learning. This result ensured what Bergmann and Sams (2012) mentioned about the benefits of using online videos and tasks in EFL classroom as students take their responsibility to learn on their own and becoming independent in their learning. Learners were able to take all the decisions concerning their learning. They were provided with greater freedom and flexibility to learn at their own pace and convenience. In addition, they learned independently and learned by interacting with their classmates and instructor. They learned from other, discussed, expressed their needs and followed up their own progress.

6. Providing feedback through online tasks encouraged students to do better and accept comments without worrying. They stayed motivated and accepted criticism. Feedback was also provided in classroom. Teacher stimulated students to work in groups and praised active students. This finding confirmed what Fulton (2012) mentioned as educators who flip their class value lectures given as assignment, as an aid to learning. Assignment is important because it is a time where students can share their learning progress with their family, be alone with their thoughts, 


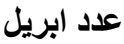

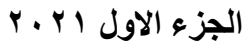

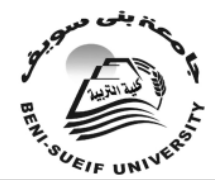

reflect on their learning, and review the material as well as the educator's feedback.

\section{Recommendations}

In the light of the results of the present research, the following recommendations are suggested:

1. Developing essay writing skills should be given more attention in the foreign language classroom. More time and effort should be used to develop them.

2. Developing students' attitude towards writing should be given more attention in the foreign language classroom.

3. Students should be given opportunities to use technology through online tasks to practise language skills freely.

\section{Suggestions for Further Research}

Further research is suggested to examine the following:

1. The effect of flipped classroom on developing other language skills (speaking, listening and reading) for university students.

2. Exploring the effect of using flipped classroom on developing students' critical writing skills.

3. Using other teaching methods for developing essay writing skills among foreign language learners in different stages.

4. Training instructors on using flipped classroom in teaching foreign language to enhance students' learning and achievement.

5. Using other modern strategies or approaches for developing essay writing skills for university students.

6. Using other teaching methods for developing students' attitude towards writing among foreign language learners in different stages. 

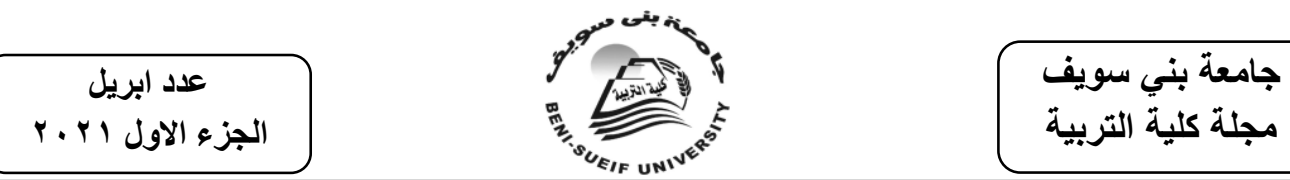

References

Afifi, A., Seleim, S., Michael, S. (2016). the effect of using of mind mapping on developing essay writing organization skills for 4th year students English section, Faculty of Education, 6th October University.

Ahmed, A. H. (2010). Students' problems with cohesion and coherence in EFL essay writing in Egypt: Different perspectives. Literacy Information and Computer Education Journal (LICEJ), 1(4), 211-221.

Alfaki, I. M. (2015). University Students' English Writing Problems: Diagnosis and Remedy, International Journal of English Language Teaching, 3(3), 40-52.

AlJaser, A. M. (2017). Effectiveness of Using Flipped Classroom Strategy in Academic Achievement and Self-Efficacy among Education Students of Princess Nourah Bint Abdulrahman University. English Language Teaching, 10(4), 67-77.

Alodwan, T. A., \& Ibnian, S. S. (2014). The effect of using the process approach to writing on developing university students' essay writing skills in EFL. Review of Arts and Humanities, 3(2), 139-155.

Al-Zahrani, A. M. (2015). From passive to active: The impact of the flipped classroom through social learning platforms on higher education students' creative thinking. British Journal of Educational Technology, 46(6), 11331148.

Ariana, S. M. (2010). Some Thoughts on Writing Skills. Annals of the University of Oradea, Economic Science Series, 19(1), 134-140.

Ariyanti, A., \& Fitriana, R. (2017). EFL students' difficulties and needs in essay writing. In International Conference on Teacher Training and Education 2017 (ICTTE 2017). Atlantis Press.

Bae, J., \& Bachman, L. F. (2010). An investigation of four writing traits and two tasks across two languages. Language Testing, 27(2), 213-234.

Bergmann, J., \& Sams, A. (2012). Flip your classroom: reach every student in every class every day. Washington, DC: International Society for Technology in Education.

Bishop, J. L., \& Verleger, M. A. (2013). The flipped classroom: A survey of the research. In ASEE national conference proceedings, Atlanta, GA,30 (9), 118.

Brown, A. F. (2012). A phenomenological study of undergraduate instructors using the inverted or flipped classroom model (Doctoral dissertation, Pepperdine University).

Bruning, R., \& Horn, C. (2000). Developing motivation to write. Educational psychologist, 35(1), 25-37.

Choi, J. (2010). The Impact of Automated Essay Scoring (AES) for Improving English Language Learner's Essay Writing (pp. 1-208). Charlottesville, VA: University of Virginia. 
Clark, K. A. (2012). Student Attitudes Towards Writing and the Effects on Writing Progress. M.A. of science in Education, Department of Education and Human Development, the State University of New York College at Brockport.

Danker, B. (2015). Using flipped classroom approach to explore deep learning in large classrooms. IAFOR Journal of Education, 3(1), 171-186.

Davies, R. S., Dean, D. L., \& Ball, N. (2013). Flipping the classroom and instructional technology integration in a college-level information systems spreadsheet course. Educational Technology Research and Development, 61(4), 563-580.

Dhadhodara, N., \& Joshi, B. (2017). The writing attitude of higher education students. Horizons of Holistic Education, 4(3-4), 111-120.

Egbert, J., Herman, D., \& Lee, H. (2015). Flipped instruction in English language teacher education: A design-based study in a complex, open-ended learning environment. Tesl-Ej, 19(2), n2.

Elashri, I. (2013). The Effect of the Genre-Based Approach to Teaching Writing on the EFL Al-Azhr Secondary Students' Writing Skills and Their Attitudes towards Writing. PhD Faculty of Education, Mansoura University.

Erdogan, T. (2013). The effect of creative drama method on pre-service classroom teachers' writing skills and attitudes towards writing. Australian Journal of Teacher Education, 38(1), 45-61.

Evans, D. (2011). Turning lessons upside down. The Times Educational Supplement, 7(4), 1-7.

Evseeva, A., \& Solozhenko, A. (2015). Use of flipped classroom technology in language learning. Procedia-Social and Behavioral Sciences, 206, 205209.

Fahim, M., \& Hashtroodi, P. (2012). The Effect of Critical Thinking on Developing Argumentative Essays by Iranian EFL University Students. Journal of Language Teaching \& Research, 3(4), 632-638.

Fawcett, S. (2010). Evergreen: A guide to writing with readings. Nelson Education. Finkel, E. (2012). Flipping the script in K12. District Administration, 48(10), 2830.

Flipped Learning Network (2014). Definition of flipped learning. Retrieved from http://flippedlearning.org/ domain/46.

Fulton, K. P. (2012). 10 reasons to flip. Phi Delta Kappan, 94(2), 20-24.

Graham, S. (2006). Writing. In Alexander, P. A., \& Winne, P. H. (Eds.), Handbook of educational psychology (pp. 457-478). Mahwah, NJ: Lawrence Erlbaum Associates.

Graham, S., Berninger, V., \& Fan, W. (2007). The structural relationship between writing attitude and writing achievement in first and third grade students. Contemporary educational psychology, 32(3), 516-536. 


$$
\begin{aligned}
& \text { عدد ابريل } \\
& \text { الجزء الاول الب ب بردي }
\end{aligned}
$$

Hamdan, N., McKnight, P., McKnight, K., \& Arfstrom, K. M. (2013). The flipped learning model: A white paper based on the literature review titled a review of flipped learning. Flipped Learning Network/Pearson/George Mason University.

Hanane, D. (2015). Students' attitudes towards academic writing: challenges facing EFL learners. Mohamed Kheider University of Biskra.

Harris, B. F., Harris, J., Reed, L., \& Zelihic, M. M. (2016). Flipped classroom: Another tool for your pedagogy tool box. In Developments in Business Simulation and Experiential Learning: Proceedings of the Annual ABSEL conference, 1(43), 325-333.

Hashemifardnia, A., Namaziandost, E., \& Shafiee, S. (2018). The effect of implementing flipped classrooms on Iranian junior high school students' reading comprehension. Theory and Practice in Language Studies, 8(6), 665-673.

Hegar, K. W. (2012). Modern human relations at work. Cengage Learning.

Houston, M., \& Lin, L. (2012). Humanizing the classroom by flipping the homework versus lecture equation. In Society for information technology \& teacher education international conference (pp. 1177-1182). Association for the Advancement of Computing in Education (AACE).

Howe, B. M. (2010). Introduction to Academic English Writing (Paperback). Ewha Womans University Press.

Ibrahim, H. (2006). The Effect of Using the Reading for Writing Approach on Developing the Writing Ability of Egyptian EFL Learners and Their Attitudes Towards Writing. Online Submission.

Kachka, P. (2012). Understanding the flipped classroom: Part 2. Teaching with Technology.

Kiester, J. B. (2013). Blowing Away the State Writing Assessment Test: Four Steps to Better Writing Scores for Students of All Levels. Maupin House Publishing, Inc.

Kim, M. K., Kim, S. M., Khera, O., \& Getman, J. (2014). The experience of three flipped classrooms in an urban university: an exploration of design principles. The Internet and Higher Education, 22, 37-50.

Kirmizi, F. S. (2008). The effect of the creative drama method on the attitude and reading strategies in Turkish teaching. Pamukkale Üniversitesi Eğitim Fakültesi Dergisi; Sayl: 23; 95-109.

Klimova, B. F. (2011). Evaluating writing in English as a second language. Procedia-Social and Behavioral Sciences, 28, 390-394.

Lan, Y. F., Hung, C. L., \& Hsu, H. J. (2011). Effects of Guided Writing Strategies on Students' Writing Attitudes Based on Media Richness Theory. Turkish Online Journal of Educational Technology-TOJET, 10(4), 148-164. 
Maghsoudi, M., \& Haririan, J. (2013). The impact of brainstorming strategies Iranian EFL learners' writing skill regarding their social class status. International Journal of language and Linguistics, 1(1), 60-67.

Milman, N. (2012). The flipped classroom strategy: what is it and how can it be used? Distance Learning, 9(3), 85- 87.

Montgomery, J. L., \& Baker, W. (2007). Teacher-written feedback: Student perceptions, teacher self-assessment, and actual teacher performance. Journal of Second Language Writing, 16(2), 82-99.

Offerman-Celentano, A. (2017). Flipped classrooms: How secondary instructors and administrators define and implement flipped instruction. St. John's University (New York), School of Education and Human Services.

Okasha, M. A., \& Hamdi, S. A. (2014). Using strategic writing techniques for promoting EFL writing skills and attitudes. Journal of Language Teaching and Research, 5(3), 674-681.

Overmyer, J. (2012). Flipped classrooms 101. Principal, 46-47.

Petric, B. (2002). Students' attitudes towards writing and the development of academic writing skills. The Writing Center Journal, 22(2), 9-27.

Roehl, A., Reddy, S. L., \& Shannon, G. J. (2013). The flipped classroom: An opportunity to engage millennial students through active learning strategies. Journal of Family \& Consumer Sciences, 105(2), 44-49.

Saed, H. A., \& Al-Omari, H. A. (2014). The effectiveness of a proposed program based on a mind mapping strategy in developing the writing achievement of eleventh grade EFL students in Jordan and their attitudes towards writing. Journal of Education and Practice, 5(18), 88-110.

Smith, C. B. (2003). Successful Use of the Six Traits in Writing. ERIC Topical Bibliography and Commentary.

Soiferman, L. K. (2017). Teaching High School Students How to Write: The Importance of Direct Explicit Instruction and Teacher Training. Online Submission.

Talbert, R. (2012). Inverted classroom. Colleague, 9 (1), 1-3.

Tucker, B. (2012). The flipped classroom. Education Next, 12(1), 82-83.

Tunks, K. W. (2010). Attitudes toward writing in fifth grade students preparing for state-mandated writing exam. International Journal of Applied Educational Studies, 8(1), 1-9.

Unakorn, P., \& Klongkratoke, U. (2015). Effectiveness of flipped classroom to mathematics learning of grade 11 students. In A Paper presented at the 21 st \& 22nd International Conference on Language, Education, and Humanities \& Innovation. Retrieved from https://icsai. org/procarch/liclehi/liclehi-44. $p d f$. 
Villalon, J., \& Calvo, R. A. (2011). Concept maps as cognitive visualizations of writing assignments. Journal of Educational Technology \& Society, 14(3), $16-27$.

Zainuddin, Z., \& Attaran, M. (2016). Malaysian students' perceptions of flipped classroom: A case study. Innovations in Education and Teaching International, 53(6), 660-670.

Zainuddin, Z., \& Halili, S. H. (2016). Flipped classroom research and trends from different fields of study. International Review of Research in Open and Distributed Learning, 17(3), 313-340. 